\title{
Dyskursywny obraz policji w czasie epidemii koronawirusa
}

\section{Bartosz Hinc}

Uniwersytet Mikołaja Kopernika w Toruniu

hinc.bartosz@gmail.com

\section{Streszczenie}

Niniejszy artykuł przedstawia analizę zdań użytych przez komendanta głównego policji generała Jarosława Szymczyka w trakcie wywiadu, za pomoca których stworzyt dyskursywny obraz policji w czasie epidemii koronawirusa. Celem artykutu było przedstawienie odpowiedzi na następujące pytania: jaki typ zdań jest dominujący w wywiadzie, w jaki sposób poszczególne typy zdań buduja dyskursywny obraz policji oraz czy wytworzony obraz jest pozytywny, czy negatywny. Tak postawione pytania badawcze wymagaty zaprojektowania badania, które oparto na analizie typów zdań budujących ideacyjna metafunkcję języka opisana $w$ teorii gramatyki funkcjonalnej Hallidaya. Zastosowanie tej metody pozwoliło na stwierdzenie, że zdania materialne, które stanowia większość zdań, przedstawiaja dynamizm oraz profesjonalizm policji, która mimo epidemii wykonuje swoje zadania w niezakłócony sposób. Zdania relacyjne demonstruja przygotowanie policjantów do walki, a także partnerskie relacje panujace $w$ policji. Zdania werbalne przedstawiaty funkcjonariuszy jako opiekuńczych $i$ zainteresowanych losem poszkodowanych. Zdania mentalne oraz behawioralne zostaty użte do pokazania, że policja działa $w$ sposób racjonalny. Natomiast zdania egzystencjalne postużyly do przedstawienia wydarzeń, w których policjanci brali udziat. Biorac wyniki analizy pod uwage, stwierdzono, że wytworzony przez gen. Szymczyka obraz policji jest pozytywny.

Stowa kluczowe: dyskursywny obraz, policja, Halliday, gramatyka funkcjonalna

Abstract

Discursive Image of the Police at the Time of Epidemic of Coronavirus

The following research demonstrates the analysis of clauses used by the Chief of Police, General Jarosław Szymczyk, during an interview which created the discursive image of the police at the time of epidemic of coronavirus. The aim of the article was to provide an answer to the following questions: which clause type dominates in the interview, how particular clauses construe the discursive image of police and whether the created image is positive or not. Such questions required a study which draws on the ideational clause type analysis described in Michael Halliday's theory of Systemic Functional Grammar. The application of the aforementioned allowed to conclude the following. Material clauses, which are the most numerous, were used to convey a dynamic and professional image of the police which, although 
had to struggle with the epidemy of coronavirus, is able to continue its work. Relational clauses were used to depict the police as an institution that is prepared to fight with the coronavirus epidemy and additionally to present that there are close bonds between police officers. Verbal clauses were used to depict police officers as caring and interested in people. Mental and behavioural clauses were used to show that the police work in a rational way. Existential clauses were used to present events in which the police offices took part. All in all, it was concluded that the discursive image created by General Szymczyk is a positive one.

Keywords: discursive image, police, Halliday, functional grammar

\section{Wstęp}

Analiza dyskursu stała się przedmiotem badań wielu dziedzin nauki, m.in. socjologii, antropologii czy językoznawstwa. Każda z nich ma właściwe dla siebie cele i metody prowadzenia badań dyskursu. Jednakże cechą wspólną, która łączy wszystkie dziedziny, jest uznanie analizy dyskursu jako badania aktualnie używanego języka w danym kontekście (Paltridge, 2012). Ludzie używają języka do realizacji rozmaitych celów, począwszy od nazywania obiektów, nawiązywania nowych relacji, a kończąc na nadawaniu sensu wypowiedzi w danym momencie (Rodney, 2012). Jest to możliwe, ponieważ użycie języka nosi cechę intencjonalności, co oznacza, że nadawca może nadać swoim słowom sens, który będzie się różnił od sensu słownikowego, odbiorca natomiast będzie w stanie to zrozumieć ze względu na kontekst. Innymi słowy, język nie jest sztywnym systemem operującym na niezmiennych danych, lecz raczej systemem mającym potencjał znaczeniowy (Wodak, 2006).

Ta cecha została dostrzeżona przez Hallidaya (2014), który za pomocą teorii gramatyki funkcjonalnej stwierdził, że język to system, w którym użytkownik, dokonując wyborów na osi paradygmatycznej, tworzy znaczenie w danym momencie. Teoria Hallidaya zakłada, że używanie języka to także realizacja trzech metafunkcji. Pierwsza z nich - funkcja ideacyjna opisuje doświadczanie świata za pomocą systemu ,przechodniości” (transitivity), który składa się z sześciu typów zdań (materialnych, mentalnych, relacyjnych, werbalnych, behawioralnych i egzystencjalnych). Funkcja interpersonalna odpowiada za przekazywanie komunikatu nadawcy. Z kolei funkcja tekstowa buduje sekwencje w dyskursie. Wobec tego założenia gramatyki funkcjonalnej stały się fundamentem wielu teorii analizy dyskursu (van Leuuwen, 2008; van Dijk, 1980).

Celem niniejszego artykułu jest wykorzystanie systemu przechodniości do analizy obrazu polskiej policji w czasie epidemii koronawirusa. Materiał badawczy stanowi wywiad komendanta głównego policji generała Jarosława Szymczyka udzielony dziennikarzowi Polskiej Agencji Prasowej. Przeprowadzona analiza ma na celu ustalenie dominującego typu 
zdań oraz określenie, czy wytworzony obraz jest pozytywny, czy negatywny. Poniższe dwie sekcje poświęcone są przedstawieniu dotychczasowych badań nad obrazem policji, a także sposobu analizy zebranego materiału, natomiast dwie kolejne sekcje prezentują wyniki badania oraz konkluzję.

\section{Badania nad obrazem policji}

We współczesnym społeczeństwie informacyjnym komunikacja odgrywa istotną rolę $\mathrm{w}$ procesie tworzenia medialnego wizerunku, a tym samym postrzegania organizacji przez społeczeństwo. Korzystny obraz instytucji przekłada się na wyższą efektywność prowadzonych przez nią działań. W przypadku instytucji zaufania publicznego, jaką niewątpliwie jest policja, pozytywny odbiór funkcjonariusza ,pozwala na coraz skuteczniejszą walkę z przestępczością, zwiększa zaufanie do prawa i organów jego ochrony oraz służy kreowaniu postaw legalistycznych wśród obywateli” (Czapska, Wójcikiewicz, 1999: 7).

Niestety, w przypadku polskiej policji kreowany obraz medialny jest zdecydowanie negatywny. Na takie przedstawienie funkcjonariuszy składa się kilka czynników. W badaniu sondażowym, przeprowadzonym wśród mieszkańców Lublina, Fil (2004) pokazuje, że osoby, które miały bezpośredni kontakt z policją, oceniały ją lepiej aniżeli osoby, które swoją wiedzę na temat jej funkcjonowania czerpały jedynie $\mathrm{z}$ telewizji. Badacz pokazuje również, że telewizja emituje programy, w których policja jest albo wyidealizowana, albo zdemonizowana, przekazując tym samym karykaturalny obraz funkcjonariuszy.

Nadmierna krytyka policji w mediach jest głównie spowodowana przez ,agresywną politykę medialną w Polsce" (Sokołowski, 2014). Media skupiają się na negatywnych wiadomościach, które eksponują niekompetencję, brutalność policji po to, aby przyciągnąć odbiorcę, a tym samym zwiększyć swoje zyski.

Warto zauważyć, że przekaz medialny dotyczący policjantów cechują dwie rzeczy: brak obiektywizmu, a także nadmierna emocjonalność. Kwestie wątpliwej obiektywności można zaobserwować w typach wiadomości, które pojawiają się w mediach. Żak (2018) zanalizowawszy treści publikowanych na temat policji przekazów, wyróżniła wśród nich trzy grupy. Na pierwszą składają się wiadomości informacyjno-interwencyjne, które informują o nieprawidłowościach w pracy policji. Do drugiej grupy należą wiadomości piętnujące, które wyrażają stanowisko autorów wiadomości dotyczących działań funkcjonariuszy. Trzecią grupę stanowią wiadomości deprawujące, które budują negatywne postawy wobec policji. O ile 
pierwszy typ nie wzbudza kontrowersji, o tyle dwa pozostałe mogą manipulować opinią publiczną, narzucając i utrwalając obraz policjantów.

Kolejnym aspektem, który świadczy o negatywnym nastawieniu mediów do policji, jest nadmierna emocjonalność przekazów. Piekarz (2019) przeprowadził badanie, w którym analizował przekazy medialne dotyczące śmierci Igora Stachowiaka ${ }^{1}$. Badacz stwierdził, że artykuły nie tylko uogólniały wydarzenia lub tworzyły iluzję obiektywności, ale także skupiały się na dramatyzacji przekazu przez użycie skrajnych pojęć czy prezentowanie brutalnych zdjęć. Na podstawie takich przekazów można zatem wysnuć wniosek, że policja jest opresyjna i wrogo nastawiona do innych.

Podsumowując, wizerunek funkcjonariuszy w mediach omawiany przez wspomnianych wyżej badaczy jest zdecydowanie negatywny. Warto jednak zauważyć, że w dotychczasowych badaniach nie analizowano obrazu policji z wykorzystaniem narzędzi dostępnych w analizie dyskursu w ujęciu językoznawczym. Tego typu analiza mogłaby pokazać m.in. dokonane wybory semantyczne, które rzutowałyby na tworzenie dyskursywnego obrazu. Warto również wspomnieć, że badacze skupiali się na tym, w jaki sposób media przedstawiają policję, jednak nie zawsze uwzględniano, w jaki sposób mówi ona sama o sobie, a tym samym jaki tworzy dyskursywny obraz. Niniejszy artykuł, wykorzystując system przechodniości, stanowi próbę wypełnienia tego braku.

\section{Badanie}

Niniejsza sekcja charakteryzuje materiał i metodę badawczą, a następnie demonstruje wyniki i konkluzję.

\subsection{Material badawczy}

Materiałem badawczym jest wywiad, jakiego 29 kwietnia 2020 roku udzielił gen. Szymczyk dziennikarzowi Polskiej Agencji Prasowej. Tekst został opublikowany na stronie internetowej PAP.

\footnotetext{
${ }^{1}$ W 2016 roku we Wrocławiu 25-letni Igor Stachowiak został niesłusznie zatrzymany przez patrol policji i przewieziony na komisariat. Na skutek brutalnego przesłuchania polegającego na wielokrotnym rażeniu paralizatorem, mężczyzna zmarł.
} 


\subsection{Metoda}

Analizę przeprowadzono za pomocą systemu przechodniości, który realizuje ideacyjną funkcję języka. System został wielokrotnie wykorzystany w analizach dyskursu, umożliwiając precyzyjną analizę danych (zob. Zhang, 2017; Seo, 2012). W tym miejscu konieczne wydaje się zaprezentowanie, w jaki sposób dokonano analizy zdań z wykorzystaniem systemu Hallidaya. Przede wszystkim w zdaniach analizowano uczestników oraz procesy. Starano się wyodrębnić podmiot i ewentualne dopełnienie, a następnie grupę nominalną i werbalną klasyfikowano do odpowiedniej kategorii na podstawie kryteriów opisanych w systemie przechodniości, np. ,policjantki i policjanci (aktor) kontrolują (proces materialny) osoby (zakres)". W ten sposób opisane zdania zostały zliczone, a liczbę wystąpień danego typu zaprezentowano na diagramie. Ze względu na objętość materiału badawczego postanowiono, że w trakcie prezentowania wyników badania przedstawione zostaną przykłady danego typu zdań. Dzięki takiej procedurze możliwe było zgromadzenie odpowiedniej ilości i jakości danych, które pozwoliły na realizację celu badania.

\subsection{Typy zdań i ich analiza}

\subsubsection{Zdania materialne}

Zdania materialne używane są po to, by pokazać proces zmiany i działania. W tym typie funkcjonariusze zajmują aktywną pozycję aktora (podmiotu) oraz przyjmują pasywną rolę celu (dopełnienia). Bycie aktorem w systemie przechodniości oznacza posiadanie wpływu na bieg wydarzeń. Policja przedstawiana jest głównie jako aktor w trakcie opisu wykonywanych obowiązków. Należy zauważyć, że wypowiedzi gen. Szymczyka prezentują dwie twarze policji: instytucjonalną oraz ludzką.

Tę pierwszą można zaobserwować w zdaniach, które opisują ustawowe obowiązki policji związane przede wszystkim z kontrolą przestrzegania obostrzeń, np. „Każdego dnia policjantki i policjanci (aktor) kontrolują (proces materialny) osoby, na których ciąży obowiązek pozostawania w kwarantannie”. Powyższy przykład sugeruje, że funkcjonariusze zostali przedstawieni jako część administracji państwowej, która realizuje postanowienia innych organów. Ponadto zdania materialne wykorzystano również do zaprezentowania działań reorganizacyjnych policji, np. „Pandemia spowodowała, że wiele firm i instytucji musiało zmienić tryb funkcjonowania. Dotyczy to także policji. Dla ograniczenia ryzyka zarażenia tam, gdzie było to możliwe, wprowadziliśmy (proces materialny) system pracy zdalnej”. Pokazuje to, że policja stara się być nowoczesną instytucją, która korzysta z rozwiązań wprowadzonych 
na wolnym rynku i nie ma obaw związanych z używaniem technologii. Co więcej, demonstruje to jej elastyczność, dzięki czemu może funkcjonować mimo zmiany trybu pracy.

Ludzki wymiar budowany jest za pomocą dyskursu policji jako opiekuna społeczeństwa polegającego na pokazywaniu działań ukazujących troskę funkcjonariuszy o bezpieczeństwo obywateli, np. ,policjanci (aktor) [...] rezygnowali (proces materialny) z urlopów czy dni wolnych, aby wesprzeć (proces materialny) kolegów i koleżanki (cel)” lub „Policjanci (aktor) rozdają (proces materialny) maseczki (cel) [...]”. W tym przypadku nadawca wypowiedzi podkreśla altruistyczne podejście funkcjonariuszy, używając czasowników: zrezygnować, rozdać, wesprzeć.

Przedstawienie obiektu jako celu oznacza, że jest on odbiorcą wykonywanego procesu i nie ma na niego wpływu. Funkcjonariusze odgrywający tę rolę w zdaniach materialnych zostali pokazani jako ofiary koronawirusa. Ilustrują to następujące przykłady: „Ponad 2300 policjantów ( $\mathrm{cel}$ ) od początku wprowadzenia stanu epidemii (okoliczność czasu) było poddanych (proces materialny) kwarantannie” oraz „Od początku walki z pandemią (okoliczność czasu) zarażonych zostało (proces materialny) ponad 130 policjantów (cel)”. Poinformowanie o liczbie poszkodowanych, która została wzmocniona przyimkiem ponad, w połączeniu z okolicznościami czasu zdań, np. „od początku wprowadzenia stanu epidemii” oraz „od początku walki z pandemią”, tworzy atmosferę dyskursu wojny, mającego uwypuklić ryzyko, na jakie narażeni są funkcjonariusze.

Interesującym elementem jest zdanie ,[...] każdemu z nich (cel) udzielono (proces materialny) pomocy, nie pozostali sami”. Mimo że komendant nie precyzuje w żaden sposób, kto oraz jakiej pomocy udzielił, to dzięki użytym czasownikom całe zdanie wnosi pozytywne wartościowanie i sugeruje, że to właśnie policja troszczy się o swoich funkcjonariuszy.

Podsumowując, dyskursywny obraz tworzony przez zdania materialne, w których funkcjonariusze występują w roli aktora, opiera się na przedstawieniu policji w ramach dwóch głównych dyskursów: policji jako elementu administracji państwowej oraz policji jako opiekuna społeczeństwa. W pierwszym przypadku akcentuje się jej rolę w kontrolowaniu przestrzegania reżimu sanitarnego, a także elastyczność w dostosowywaniu się do nowego, zdalnego trybu pracy. Natomiast w drugim przypadku podkreślone zostaje altruistyczne podejście funkcjonariuszy do obywateli, które buduje się przez użycie takich czasowników jak: rezygnować, wspierać, rozdawać. Zdania materialne, w których policjanci pełnią funkcję celu, przedstawiają ich w ramach dyskursu wojennego jako ofiary walki z wirusem. 


\subsubsection{Zdania relacyjne}

Zdania relacyjne służą do tego, aby opisać bycie lub posiadanie. Wyróżnia się dwa typy zdań: atrybutywne oraz identyfikacyjne. Zdania atrybutywne przypisują odpowiednią charakterystykę podmiotowi nazywanemu nosicielem (ang. carrier) przez dopełnienie określane jako atrybut.

Dyskursywny obraz policji, jaki budowany jest za pomocą tych zdań, polega na przedstawieniu jej przygotowania do walki z epidemią, np. „Policjanci (nosiciel) są zaopatrzeni (proces relacyjny: atrybutywny) w środki ochrony osobistej (atrybut) [...] Do chwili obecnej wydanych zostało miliony maseczek, rękawiczek, worków na odpady, do tego tysiące skafandrów, gogli i setki tysięcy litrów płynów dezynfekujących”. Wyliczenie środków ochrony ma pokazać, że traktuje się kwestie bezpieczeństwa funkcjonariuszy priorytetowo, a także by zademonstrować sprawność w rozdystrybuowaniu dodatkowego wyposażenia.

Zdania identyfikacyjne opisują przynależność podmiotu nazywanego tokenem do danej klasy, grupy przez dopełnienie określane mianem wartości (ang. value). Ten typ zdań został użyty, aby zaprezentować obraz odpowiedzialnego kierownictwa, które dokłada starań do zapewnienia policjantom ochrony w czasie wykonywania obowiązków, np. „Bezpieczeństwo moich ludzi (token) jest (proces relacyjny: identyfikacyjny) dla mnie i całego kierownictwa polskiej Policji najważniejsze (wartośćc)". Dzięki temu odbiorca wypowiedzi tworzy obraz policji, która dba o siebie.

Zdania identyfikujące zostały również użyte, by pokazać, że policja chce ułatwiać życie obywatelom, np. „Naszą rolą (token) jest (proces relacyjny: identyfikacyjny) wspomaganie obywateli (wartość) w różnych sytuacjach”. Świadczy to o tym, że rola funkcjonariuszy nie ogranicza się do pełnienia funkcji aparatu represyjnego, lecz polega na tym, aby być dla społeczeństwa wsparciem.

Podsumowując, zdania relacyjne wykorzystano do uwypuklenia poziomu przygotowania policji do walki z wirusem, a także podkreślenia, że kierownictwo dba o bezpieczeństwo policjantów na służbie. Warto również zauważyć, że ten typ zdań został użyty w celu położenia nacisku na prospołeczne nastawienie funkcjonariuszy, którzy pragną pomagać społeczeństwu.

\subsubsection{Zdania werbalne}

Zdania werbalne używane są głównie do nadawania komunikatu. Nadawca określany jest mianem mówiącego, a jego komunikat jako verbiage. Zdania werbalne, podobnie jak zdania materialne, pokazują dwie twarze policji: ludzką oraz instytucjonalną. 
Pierwsza oparta jest na dyskursie policji jako opiekuna społeczeństwa i ma na celu wzbudzenie zaufania obywateli do funkcjonariuszy. Obrazują to sytuacje kontrolowania osób przebywających na kwarantannie i jednocześnie będących ofiarami przemocy domowej, np. „[...] poleciłem (proces werbalny) dzielnicowym, aby nawiązali kontakt (proces werbalny) z ofiarami przemocy domowej” oraz „Policjanci (mówiący) [...] często rozpytywali (proces werbalny), jak wygląda atmosfera w domu, czy osoby te czegoś nie potrzebują itp”. Używając czasowników jak polecić, nawiązać kontakt, rozpytywać, generał pokazuje, że policja angażuje się w sprawdzenie bezpieczeństwa domowników w czasie kwarantanny oraz stara się być blisko problemów obywateli.

Zdania werbalne zostały użyte, aby zwrócić się do społeczeństwa, np. „Wszystkim (odbiorca), którzy dostrzegają i doceniają nasze zaangażowanie oraz rozumieją ryzyko, na jakie się narażamy, serdecznie dziękuję (proces werbalny)”. W tym przypadku użycie czasownika dziękować pokazuje wdzięczność za zrozumienie wykonywanych obowiązków. Dzięki temu typowi zdań promowany jest również dyskurs współpracy z policją, np. „Nie wstydźcie się Państwo (mówiacy) powiedzieć (proces werbalny) nam (odbiorca), że jesteście zarażeni koronawirusem lub że przebywacie w kwarantannie [...]. Jeśli nie będziemy wiedzieli, że jesteśmy zarażeni, wówczas możemy nieświadomie zarażać innych”. Generał stara się przekonać społeczeństwo, że mówienie prawdy i informowanie o swoim stanie zdrowia przyczyni się do skuteczniejszej walki z wirusem.

Z kolei instytucjonalna twarz pojawia się w ramach dyskursu policji jako strażnika prawa wtedy, gdy mowa jest o przestępcach oferujących rzekome leki na koronawirusa i zwalczaniu tego procederu, np. „Apeluję (proces werbalny) o ostrożność, na naszych stronach internetowych oraz profilach społecznościowych informujemy (proces werbalny) o metodach oszustów. Chciałbym także podkreślić (proces werbalny), że cały czas równie mocno jak wcześniej ścigamy przestępców". W powyższych wypowiedziach możemy zaobserwować, że dzięki użyciu czasowników jak: apelować, informować, podkreślać oraz przysłówka równie mocno wyłania się obraz silnej policji, która nie ustaje w walce z przestępczością.

Reasumując, zdania werbalne prezentują dwa główne dyskursy, tj. policji jako opiekuna społeczeństwa oraz policji jako strażnika prawa. Ten pierwszy objawia się w sytuacjach, gdy funkcjonariusze dopytują czy ofiary przemocy domowej będące na kwarantannie są bezpieczne. Ponadto promuje się współpracę z policją, ponieważ bycie szczerym i informowanie o swoim stanie zdrowia powoduje, że policjanci mogą się dodatkowo zabezpieczyć, a tym samym ograniczyć rozprzestrzenianie wirusa. Warto zwrócić uwagę na to, że generał wyraża wdzięczność za okazywane zrozumienie, co pokazuje, że policja nabiera 
ludzkiego wymiaru. Z kolei dyskurs policji jako strażnika prawa daje się zauważyć w apelach komendanta, który ostrzega o przestępczej aktywności związanej z handlem rzekomymi lekami na koronawirusa.

\subsubsection{Zdania mentalne}

Zdania mentalne pokazują procesy kognitywne, afektywne oraz percepcję. Podmiot będący wykonawcą procesu nazywany jest czującym (ang. senser), a dopełnienie procesu określa się mianem fenomenu.

Ten typ zdań wykorzystano, aby przedstawić policję jako formację, która kieruje się racjonalnością przy podejmowaniu decyzji, np. „Policja zawsze podejmuje interwencje, ale wiedząc (proces mentalny) o zagrożeniu, funkcjonariusze mogą się dodatkowo zabezpieczyć” oraz „Jeśli nie będziemy wiedzieli (proces mentalny), że jesteśmy zarażeni, wówczas możemy nieświadomie zarażać innych”. Dzięki czasownikowi wiedzieć, który należy do grupy czasowników kognitywnych, opisujących procesy myślowe, pokazuje się społeczeństwu, że informowanie funkcjonariuszy o zagrożeniu pomoże ograniczyć rozprzestrzenianie się wirusa.

Kolejny przejaw racjonalności można zaobserwować w połączeniu zdań mentalnych i materialnych, kiedy generał przedstawia sprostowanie odnośnie do filmów pokazujących rzekomą brutalność policjantów w czasie epidemii, np.

Nie ma naszej zgody na bezprawne i fałszywe oskarżenia! Nie mają one nic wspólnego z koronawirusem i naszymi działaniami. Tymczasem celowo próbuje się budować obraz brutalnej policji. Trzeba pamiętać (proces mentalny) też, że w ogromnej większości udostępniane filmy pokazują (proces mentalny) tylko fragment całości. Najczęściej oczywiście ten, kiedy dochodzi już do stosowania środków przymusu bezpośredniego.

Wypowiedź miała wyjaśnić, że filmy prezentujące brutalność policji zostały poddane celowej manipulacji, aby pokazać bezwzględność funkcjonariuszy. Ponadto są niezwiązane z kontrolowaniem przestrzegania obostrzeń w czasie epidemii.

Istotne jest również zwrócenie uwagi na język użyty w zaprezentowanych tłumaczeniach. Generał, stosując konstrukcje w stronie biernej, nie precyzuje, kto ani w jakim celu miałby budować negatywny wizerunek policji. Czytelnik nie jest również poinformowany o tym, czy pozostałe filmy, przedstawiające całość interwencji, pokazują słuszność zarzutów, czy też nie. Co więcej, wykorzystywane są terminy prawnicze, jak np. środki przymusu bezpośredniego, oznaczające użycie siły wobec obywatela. Wymienione cechy są charakterystyczne dla stylu urzędniczego, który akcentuje dyskurs policji jako instytucji. 
W dalszej części wypowiedzi generał wyjaśnia, że w związku z dużą liczbą interwencji oraz koniecznością szybkiego podejmowania decyzji funkcjonariusze popełniają błędy, np.

Każdej doby policjanci przeprowadzają wzorowo ok. 15-16 tys. interwencji, do tego dochodzi ok. 15 tys. kontroli drogowych. Niestety przy takim ogromie pracy i w sytuacjach, gdy często policjant ma na podjęcie decyzji (proces mentalny) kilka sekund zdarzają się sporadyczne błędy, ale szybko wyciągamy wnioski (proces mentalny) i robimy, co możliwe, aby nie powtórzyły się w przyszłości.

Ważne jest to, że policjanci są świadomi niewłaściwych decyzji, które analizują, aby wyciągnąć odpowiednie wnioski na przyszłość. Warto jednak zauważyć, że nieprawidłowości nazwano błędami. Jest to próba umniejszenia roli funkcjonariusza w zdarzeniu, a także zmniejszenie konsekwencji niewłaściwego działania, ponieważ czytelnik nie wie, czy w wyniku błędu na przykład ktoś nie stracił życia lub doznał uszczerbku na zdrowiu. Pokazuje to, że niedopełnienie obowiązków traktowane jest jako zjawisko, które po prostu się zdarza. Nie rozpatruje się go w charakterze czyjejś krzywdy, a tym samym odbiera się mu ludzki, a nadaje abstrakcyjny wymiar.

Podsumowując, zdania mentalne zostały użyte, aby zakomunikować opinii społecznej racjonalny charakter działań policji, który polega na podejmowaniu decyzji w oparciu o analizę faktów. Komendant podkreśla, że policja bada popełniane przez funkcjonariuszy błędy i stara się z nich wyciągnąć wnioski na przyszłość.

\subsubsection{Zdania behawioralne}

Zdania behawioralne są typem granicznym zdań, ponieważ posiadają cechy zdań materialnych oraz zdań mentalnych i używa się ich do pokazania zachowania. Najczęściej występują one w konfiguracji podmiotu nazywanego behaver oraz procesu.

Zdania behawioralne zostały użyte, aby - podobnie jak zdania mentalne - pokazać racjonalizm policji. Można to zaobserwować na następujących przykładach: „Dlatego bacznie się temu przyglądamy (proces behawioralny), dzielnicowi cały czas utrzymują kontakt z rodzinami” lub „obserwujemy (proces behawioralny) za to przestępczą aktywność związaną z koronawirusem". Użycie takich czasowników jak przyglądać się, obserwować podkreśla, że funkcjonariusze analizują fakty i na tej podstawie podejmują dalsze decyzje. 


\subsubsection{Zdania egzystencjalne}

Zdania egzystencjalne wprowadzają tło sytuacji poprzez prezentację obecnych elementów w sytuacji lub wydarzeń, które miały już miejsce. Składają się one z jednego elementu, który nazywany jest istniejącym (ang. existent).

Użycie zdań egzystencjalnych w wywiadzie miało na celu nakreślenie tła wydarzeń, które następnie rozwijane jest przy użyciu innych typów zdań, np. „Większość tych filmów to zapisy z różnych sytuacji, które miały miejsce (istniejacy), dawno temu” lub „Były przypadki (istniejący), gdy z 1,5 godzinnych czynności [...]”. Dostarczanie szczegółów w trakcie prezentowania swojego punktu widzenia ma za zadanie uwiarygodnianie wypowiedzi w oczach czytelnika.

\section{Wnioski}

Przeprowadzona analiza pokazała, że do wytworzenia dyskursywnego obrazu policji w czasie pandemii koronawirusa wykorzystano sześć typów zdań. Na rycinie 1 zaprezentowano procentowy i liczbowy rozkład użytych zdań. Każde z nich buduje dyskursy, które zostały omówione poniżej.

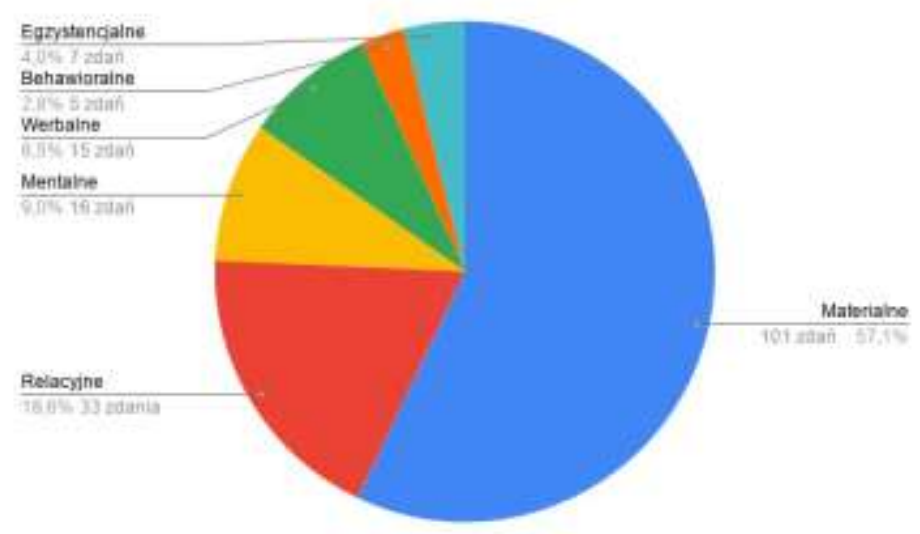

Rycina 1. Procentowy i liczbowy udział sześciu typów zdań. Źródło: Opracowanie własne.

W przypadku dominujących zdań materialnych, w których funkcjonariusze występują w roli aktorów, przedstawiają one policję w ramach dyskursu dynamicznej formacji skupionej na działaniu, cechującej się pewnym dualizmem. Z jednej strony policja pokazuje instytucjonalną, a z drugiej ludzką twarz.

Ta pierwsza powstaje w momencie opisywania kontroli przestrzegania obostrzeń i prowadzi do tego, że jest ona odbierana jako mechanizm aparatu państwowego. Instytucjonalna twarz możliwa jest również do zauważenia w opisie działań reorganizacyjnych policji. 
Podkreśla się, że mimo swoich rozmiarów zmiana trybu pracy na zdalny nie wpłynęła na prowadzoną działalność.

Z kolei ludzka twarz budowana jest na podstawie altruistycznej postawy funkcjonariuszy, która zostaje uwypuklona przez informowanie o rozdawaniu maseczek czy też o tym, że policjanci rezygnują ze swoich wolnych od pracy dni, aby wspomóc kolegów i koleżanki na służbie. Pokazuje to, że policjanci działają jako opiekunowie społeczeństwa i chcą mu zapewnić jak najlepszą ochronę.

Funkcjonariusze występują również w roli celu i dzięki metaforze wojennej, przedstawia się ich jako ofiary w walce z wirusem. Świadczą o tym np. liczba zarażonych oraz poddanych kwarantannie lub okoliczniki czasu jak od początku walki z pandemia czy od początku wprowadzenia stanu epidemii.

Zdania relacyjne posłużyły do tego, aby przedstawić policję jako dobrze przygotowaną instytucje do walki z wirusem. Za pomocą tego typu zdań eksponuje się obraz kierownictwa policji, które traktując priorytetowo bezpieczeństwo funkcjonariuszy na służbie, zorganizowało wszelkie niezbędne środki do ochrony przed zakażeniem. Ponadto zdania relacyjne, jak wcześniejsze zdania materialne, opisują altruistyczną postawę funkcjonariuszy względem obywateli, którzy mimo ryzyka zakażenia, chcą im pomagać i się o nich troszczyć.

Zdania werbalne prezentują funkcjonariuszy w ramach dyskursu opiekuna społeczeństwa oraz strażnika prawa. Pierwszy z nich widoczny jest, gdy policjanci upewniają się, że ofiarom przemocy domowej będącym jednocześnie na kwarantannie nic nie grozi. Pokazuje to, że policja stara się być opiekuńcza wobec słabszych oraz stać blisko obywatela i rozwiązywać jego problemy. Ponadto zdania werbalne zostały użyte, aby wyrazić wdzięczność komendanta za okazywane zrozumienie prowadzonych przez funkcjonariuszy działań. Istotny jest również dyskurs współpracy z policją, który objawia się przede wszystkim mówieniem prawdy o swoim stanie zdrowia, gdyż bycie szczerym może uchronić policjantów czy innych ludzi przed zakażeniem.

Natomiast w drugim przypadku policja występuje jako instytucja stojąca na straży prawa. Można to zauważyć zwłaszcza w momencie np. apelowania do społeczeństwa o ostrożność i czujność w związku z nowymi schematami działań przestępców. Warto dostrzec, że generał podkreśla, że mimo epidemii, policja nie ustaje w ściganiu przestępców, co uwypukla obraz silnej, niezachwianej przez epidemie formacji, która kontynuuje swoją działalność.

Zdania mentalne, podobnie jak zdania behawioralne, prezentują działania policjantów w ramach dyskursu racjonalizacji, który objawia się w sytuacjach, gdy funkcjonariusze zakładają dodatkową odzież ochronną w przypadku interwencji u osoby zarażonej, a także kiedy 
komendant wyjaśnia użycie siły przez policjantów przedstawione na filmach. Tłumaczy on, że materiały zostały zmanipulowane w taki sposób, aby pokazywać brutalność policji. Co więcej, przyznaje, że niekiedy interwencje nie przebiegały w regulaminowy sposób i w związku z tym były poddane analizie w celu wyciągnięcia odpowiednich wniosków, które pozwoliłyby na uniknięcie podobnych sytuacji w przyszłości. W tym momencie komendant korzysta również z urzędniczego stylu wypowiedzi, który cechują m.in. użycie strony biernej, zdań wielokrotnie złożonych czy specyficznego słownictwa. W związku z tym wspomniane aspekty tworzą obraz policji jako instytucji, która kieruje się faktami przed podjęciem decyzji, uczy się na błędach i stara się, aby funkcjonariusze wykonywali obowiązki w profesjonalny sposób.

Z kolei zdania egzystencjalne dostarczają szczegółów opisywanych zdarzeń i tworzą tło dla zdarzeń, które są następnie rozwijane przez pozostałe typy zdań. Przedstawienie konkretnych informacji o zdarzeniu ma na celu przede wszystkim uwiarygodnianie wypowiedzi.

Podsumowując, dyskursywny obraz policji w czasie epidemii koronawirusa budowany jest przez liczne dyskursy, które zdają się grupować w dwa makrodyskursy, tj. policji jako uosobienia mocy państwa oraz policji jako opiekuna społeczeństwa. Warto zauważyć, że wpisują się one w coraz częściej eksponowany dyskurs policji „,pomagamy i chronimy” mający na celu przedstawienie funkcjonariuszy w pozytywnym świetle.

\section{Bibliografia}

Czapska, Janina, Józef Wójcikiewicz (1999) Policja w społeczeństwie obywatelskim. Kraków: Zakamycze.

Figaj, Bartłomiej (2020) Komendant Główny Policji: każdego dnia polskie ulice patroluje do 25 tys. funkcjonariuszy. Polska Agencja Prasowa [pobrane z https://www.pap.pl/aktualnosci/news\%2C635152\%2Ckomendant-glowny-policjikazdego-dnia-polskie-ulice-patroluje-do-25-tys. Data ostatniego dostępu: 09.12.2020].

Fil, Kamil (2004) „Wizerunek policji w opinii mieszkańców Lublina”. Annales Universitatis Mariae Curie-Skłodowska 11; 141-151.

Halliday, Michael (2014) Halliday's Introduction to Functional Grammar. London: Routledge.

Jones, Rodney (2012) Discourse Analysis: A Resource Book for Students. London: Routledge.

Paltridge, Brian (2012) Discourse Analysis. London: Bloomsbury. 
Piekarz, Michał (2019) „Śmierć Igora Stachowiaka a skandalizacja medialnego obrazu polskiej policji”. [W:] Rafał Klepka, Jakub Idzik (red.) Medialne obrazy świata. Kraków: Wydawnictwo Naukowe Uniwersytetu Pedagogicznego; 33-47.

Seo, Soa (2012) "Hallidayean Transitivity Analysis: The battle for Tripoli in the Contrasting Headlines of Two National Newspapers.” Discourse \& Society 24 (6); 774-791. https://dx.doi.org/10.1177/0957926513503267.

Sokołowski, Mariusz (2014) „Działalność prasowo-informacyjna instytucji publicznej na przykładzie polskiej policji”. Studia Politologiczne 34; 211-255.

van Dijk, Teun (1980) Macrostructures. An Interdisciplinary Study of Global Structures in Discourse, Interaction and Cognition. Hillsday: Lawrence Erlbaum Associates.

van Leuuwen, Theo (2008) Discourse and Practice: New Tools for Critical Discourse Analysis. Oxford, New York: Oxford University Press.

Wodak, Nicole (2006) Describing Discourse: A Practical Guide to Discourse Analysis. London: Hodder Arnold.

Zhang, Yichao (2017) „Transitivity Analysis of Hillary Clinton’s and Donald Trump’s First Television Debate.” International Journal of Applied Linguistics \& English 6 (7); 65-72. http://dx.doi.org/10.7575/aiac.ijalel.v.6n.7p.65.

Żak, Monika (2018) „Medialny obraz świata. Rola mediów w kształtowaniu wizerunku policji”. Media i społeczeństwo 8; 115-125. 